\title{
RECENT ADVANCES IN POST-TRANSLATIONAL REGULATION OF PLANT DEFENSE RESPONSES BEYOND PHOSPHORYLATION
}

\author{
$\underline{\text { Tim XING }}^{1 *}$, Ziwei GUO ${ }^{1}$ \\ ${ }^{1}$ Department of Biology and Institute of Biochemistry, Carleton University, Ottawa, Ontario - Canada. \\ * Corresponding author. E-mail: tim.xing@ carleton.ca
}

\begin{abstract}
During plant-microbe interactions, plant immune signaling relies significantly on post-translational modifications (PTMs) to induce rapid downstream changes. Organization at protein level is extensively complex and various forms of PTMs of transcript products provide a unique system in maintaining such an organization. With current proteomic research some detailed mechanisms of these PTMs have started to be uncovered. Pathogens also take PTMs as a virulence strategy to overturn host immunity through the activities of their effector proteins. In this review, we will address the importance of PTMs other than phosphorylation in plant defense response.
\end{abstract}

Keywords: acetylation, glycosylation, plant defense, post-translational modification, SUMOylation, ubiquitination.

\section{Introduction}

Plants are under constant interaction with pathogens. Unlike mammals, which have highly specialized immune cells that can migrate to all parts of body, plants have evolved strategies that upon infections cells are regulated to achieve immunity responses [WITHERS \& DONG, 2017]. There are two main types of molecular immunity response, pathogen-associated molecular pattern (PAMP)-triggered immunity (PTI) and effector-triggered immunity (ETI). Conserved microbial elicitors called pathogen-associated molecular patterns are recognized by pattern recognition receptors (PRRs) on the external surface of the plant cell [DODDS \& RATHJEN, 2010; NEWMAN \& al. 2013]. ETI can be initiated by cell surface perception or intracellular perception [XING \& al. 2017]. PRRs can recognize PAMP and host-derived damage-associated molecular patterns (DAMPs) to activate immune response [XING \& al. 2017]. Examples of these molecular patterns are pathogen cell wall components including lipopolysaccharides, peptidoglycan, chitin, and proteins including flagellin, EF-TU and host produced substances (DAMPs) including plant peptides (PEP), oligogalacturonides and extracellular ATP [TREMPEL \& al. 2016]. The ligand recognition by PRR activates downstream signaling pathways and eventually trigger defense response such as transcription of defense-related genes, production of antimicrobial compounds, influx of $\mathrm{Ca}^{2+}$, rapid burst of reactive oxygen species (ROS), and hypersensitive response (HR) [BIGEARD \& al. 2015; TREMPEL \& al. 2016]. Through evolution, pathogens have developed mechanisms to deliver pathogen effectors into plant cells to overcome plant PTI. As such, plants have developed $R$ gene products to recognize pathogen effectors and activate ETI. ETI is significantly stronger than PTI and can lead to HR and massive transcriptional reprogramming [XING \& al. 2017]. ETI also triggers systemic acquired resistance (SAR), which act away from the infection site to protect the whole plant [CUI \& al. 2015; WITHERS \& DONG, 2017]. 
To ensure a rapid switch of signaling pathway and the correct activation of immune response, components of plant defense signaling pathways are under precise regulation through PTMs. PTM plays roles in both the activation and the inhibition of PTI and ETI [WITHERS \& DONG, 2017]. Phosphorylation is one of the most commonly used and the best studied PTM in plant defense response [XING \& LAROCHE, 2011; XING \& al. 2017]. Besides phosphorylation, other PTMs also play critical roles. In some cases, they may not directly pass immune signals to downstream components but can take part in maintaining the normal function of signaling components or attenuating immune response [WITHERS \& DONG, 2017]. In this review, the role of these other PTMs including ubiquitination, glycosylation, SUMOylation, and acetylation on plant immunity is discussed with the focus on some highly regulated defense components.

\section{Ubiquitination regulates PTI through degradation of existing components}

Remodeling of the plasma membrane (PM) protein composition is emerging as a key aspect regulating receptor signaling and mediating signal resolution in space and time. Receptor ubiquitination may regulate protein levels by modulating PRR traffic at different stages after endocytosis. Following internalization, cargoes go through a sorting process, which decides whether they will be recycled and returned to the PM, or transported to the vacuole for degradation [WITHERS \& DONG, 2017]. In the secretory pathway, components of the endoplasmic reticulum (ER)-quality control ensure the proper accumulation and function of PRRs such as FLS2 receptors [WITHERS \& DONG, 2017].

Upon flg22 perception, Arabidopsis BAK1 and PUB12/13 associate with FLS2. BAK1 phosphorylates PUB 12/13 to induce the polyubiquitination of cytosolic domain of FLS2, which leads to the degradation of FLS2 by $26 \mathrm{~S}$ proteasome [LU \& al. 2011]. PUB 12/13-deficient mutant display enhanced immune responses and ROS production upon flg22 perception [LU \& al. 2011]. The recruitment of E3 ligases to FLS2 modulates PTI through the attenuation of immune signaling [LU \& al. 2011]. CERK1 is a membrane localized receptor-like kinase that can activate PTI by sensing chitin and chitosan [YAMAGUCHI \& al. 2017]. Similar to FLS2, PUB12-CERK1 interaction upon the recognition of chitin targeted CERK1 for degradation and attenuated immune response [YAMAGUCHI \& al. 2017].

Interestingly, PRRs also regulate the activity of ubiquitin ligase and hence facilitate downstream immune response. In rice, PID2, a transmembrane lectin receptor-like kinase, confers resistance to Magnaporthe oryzae infection [CHEN \& al. 2006]. OsPUB15, a rice Ubox/ARM repeat protein, is reported to possess E3 ligase activity and interact with PID2 [WANG \& al. 2015]. Upon PAMP recognition, activated PID2 proteins homo-dimerize to phosphorylate OsPUB15 to activate its E3 ligase function. Overexpression of OsPUB15 upregulated expression of pathogenesis-related (PR) genes, increased ROS production, and enhanced resistance to rice blast [WANG \& al. 2015]. Based on these findings, OsPUB15 acts as an inducer of PID2-triggered immunity and up-regulates PTI [WANG \& al. 2015].

Ubiquitination of cytosolic components of PTI signaling pathway also contributes to the regulation of PTI. The regulation of BIK1 is explained by the modulation of non-activated and activated BIK1 pools [WANG \& al. 2018]. E3 ubiquitin ligase PUB25 and PUB 26 negatively regulate PTI by targeting the degradation of non-activated BIK1 [WANG \& al. 2018]. In this model, CPK28, heterotrimeric G proteins (AGG1, AGG2, XLG2, and AGB1), and PUB25/26 together regulate BIK1-induced downstream immune responses [WANG \& al. 2018]. Before pattern recognition, BIK1 is not phosphorylated by FLS2 and is susceptible to PUB25/26 mediated degradation. Heterotrimeric G proteins associate with FLS2-BIK1 complex 
Tim XING \& Ziwei GUO

and stabilize BIK1 by inhibiting PUB25/26 E3 ligase activity [LIANG \& al. 2016]. Upon pattern recognition, BIK1 is phosphorylated by FLS2 and activated [WANG \& al. 2018]. The perception of flg22 by FLS2 increases the phosphorylation of PUB25/ 26 by CPK28 and hence the E3 ligase activity of PUB25/26 [WANG \& al. 2018]. However, PUB25/26 do not have ligase activity on activated BIK1 but non-FLS2 interacting BIK1 is rapidly removed by active PUB25/26 [WANG \& al. 2018]. Ubiquitination of BIK1 modulates PTI by retaining necessary signaling and removing excess signaling component to prevent unnecessary immune response [WANG \& al. 2018].

PUB4, a CERK1-interacting E3 ubiquitin ligase, has also been reported to regulate immunity by ubiquitinating BIK1 [DERKACHEVA \& al. 2020]. Arabidopsis Pub4 mutant display reduced ROS burst upon flg22 and elf8 treatment, suggesting that PUB4 positively regulates PTI [DERKACHEVA \& al. 2020]. PUB4 associates with FLS2/EFR-BIK1 complex and targets the degradation of only non-activated BIK1 [DERKACHEVA \& al. 2020]. The E3 ligase up-regulates downstream immune response and ROS burst and acts as a positive regulator of PTI by promoting the accumulation of activated BIK1 upon PAMP perception [DERKACHEVA \& al. 2020]. The degradation of non-active BIK1 stabilizes the system in a resting state, which contributes to the activation of immunity in this case.

\section{Glycosylation is required for the normal function of receptors of PTI}

Protein glycosylation is required for ER/Golgi processing and trafficking of membrane proteins to plasma membrane [TREMPEL \& al. 2016]. Oligosaccharyl transferase (OST) complex in the ER lumen is significantly involved in the regulation of asparagine-linked glycosylation ( $N$-glycosylation) in ER [AEBI, 2013]. Tunicamycin (TM), an $N$-glycosylation inhibitor, weakens overall immune system and disturbs ER quality control (ERQC) [CHAKRABORTY \& al. 2017]. $N$-glycosylation of PRR is required for the localization of PRR to PM and ligand binding of PRR [AEBI, 2013]. STT3A gene encodes a subunit of OST and is critical for $N$-glycosylation in ER [HÄWEKER \& al. 2010]. STT3A loss-of-function mutant has showed that $N$-glycosylation plays critical function for the EFR ligand binding and translocation to PM [HÄWEKER \& al. 2010; FARID \& al. 2013]. A single loss of EFR ${ }^{\mathrm{N} 143}$ glycosylation site in the leucine-rich repeat (LRR) ectodomain impaired the receptor stability and ligand recognition but not its translocation from ER to PM [HÄWEKER al. 2010]. Unlike EFR, FLS2 is relatively insensitive to mutation of putative $N$-glycosylation sites [SUN \& al. 2012]. However, this does not mean that flg22-trigger PAMP signaling is independent of $N$ glycosylation. Studies found that flg22 induced pathogenesis-related protein 1 (PR1) accumulation is lowered in stt3a [KANG \& al. 2015] and FLS2 with octuple-PGS [putative $N$ linked glycosylation sites] mutations partially lost flg22 responsiveness [SUN \& al. 2012]. In tomato Cf-9, all PGSs except PGS18 were shown to be $N$-glycosylated and all of the glycosylation sites were important for Cf-9 activity [VAN DER HOORN \& al. 2005].

When wild type plant was treated with TM, the binding of ligand and translocation to PM of FLS2 was impaired [HÄWEKER \& al. 2010]. Upon the perception of PAMP by PRR, extracellular calcium influxes into cytoplasm. As a result, under-glycosylation of PRR should display impaired calcium influx. Arabidopsis cce2/cce3 mutants display reduced calcium elevations after treatment with MAMP or DAMP including flg22, elf18, chitin, LPS and AtPep1 [TREMPEL \& al. 2016]. CCE2/CCE3 encode $\alpha$-1,3-mannosyltransferase, ALG3, and its activity in alg3 mutant was reduced and PRRs of cce2/cce3 were under-glycosylated but they were still localized to PM [TREMPEL \& al. 2016]. This seems to indicate that $N$-glycosylation of PRRs is responsible for calcium elevation of PTI signaling [TREMPEL \& al. 2016]. Similar 
results were observed in Arabidopsis ccel mutant with a mutated ALG12 [TREMPEL \& al. 2020].

Chitosan oligosaccharide (COS), generated by enzymatic hydrolysis of chitosan, can have priming effect on plant-pathogen interaction by enhancing PR1 expression and activating salicylic acid (SA)- and/or jasmonic acid (JA)-dependent signaling pathway [JIA \& al. 2018]. The increase of resistance of plant by COS involves glycosylation. Stt3a and ManI mutants are $N$-glycosylation impaired and are more susceptible to Pst DC3000 infection [JIA \& al. 2018]. However, Pst DC3000 infection was rescued in Stt3a and ManI mutants by pretreatment with COS [JIA \& al. 2018]. This indicates the under-glycosylation of immune signaling components is restored by COS. Also, COS-pretreated and Pst DC3000-infected plants showed differences in the accumulation of nucleotide sugar donors [JIA \& al. 2018]. The finding indicates that $N$ glycosylation of plant innate immune response and COS induced resistance are regulated via partially non-overlapping pathways [JIA \& al. 2020].

Defection in $\mathrm{N}$-glycosylation was also shown to up-regulate some defense responses [CHAKRABORTY \& al. 2017]. TM treatment induced PR1 expression independently of PTI but the increased PR1 did not enhance pathogen resistance, possibly offset by the negative effect of ER stress and the negative effect of under-glycosylation of plant defense pathways on the immunity. As PR1 is a PTI activation marker and a SAR (systemic acquired resistance) mediator, this study seems to indicate that inhibition of $N$-glycosylation could trigger some plant immune responses even though the pathway is unknown. [CHAKRABORTY \& al. 2017].

\section{SUMOylation affects protein-protein interaction}

SUMOylation is similar to ubiquitination, where E1, E2, and E3 enzymes are involved. SUMOylation modulates protein stability, protein-protein interaction and protein subcellular localization, and is involved in plant defense mechanism [NIU \& al. 2019]. An example is SCE1, an Arabidopsis SUMO E2 enzyme, which induces SUMO1/2 conjugation to suppress immune response [SKELLY \& al. 2019]. Upon pathogen recognition, the increased nitric oxide (NO) level induced $S$-nitrosylation of SCE1 at Cys139, suppressed SCE1-mediated SUMOylation and hence up-regulated immune response [SKELLY \& al. 2019].

As a master regulator of basal and SAR, NPR1 confers immunity through a transcriptional cascade including transcription activators (e.g. TGA3) and repressors (e.g. WRKY70) [FU \& DONG 2013; SALEH \& al. 2015]. SA accumulation promoted dephosphorylation of Ser55/Ser59 through an unknown mechanism and induced SUMOylation of NPR1, resulting in dissociation from WRKY70 and inactivation of this repressor [SALEH \& al. 2015]. Modification of NPR1 by SUMO3 was required for its phosphorylation at Ser11/Ser15 to form a signal amplification loop to generate more activated NPR1 [SALEH \& al. 2015]. This activated form of NPR1 interacted with the TGA3 transcription activator to induce PRI gene expression [SALEH \& al. 2015]. Subsequently, the modified NPR1 was ubiquitinated and targeted for degradation by the $26 \mathrm{~S}$ proteasome mediated by interaction with NPR3 to ensure the transient nature of the immune induction [SALEH \& al. 2015].

SUMOylation on PRR is required for progression of PTI signaling pathway. FLS2, BAK1 and BIK1 form complex during flg22 perception [TANG \& al. 2017]. SUMOylation of FLS2 promoted the dissociation of activated BIK1 from the complex to allow downstream BIK1 induced signaling [TANG \& al. 2017]. Desi3a, one of the eight Desi type SUMO proteases, deSUMOylated FLS2 to down-regulate immune response [OROSA \& al. 2018]. The amount of Desi3a was reduced when flg22 was present, suggesting that Desi3a take part in maintaining the system in the resting state in non-pathogenic conditions [OROSA \& al. 2018]. 


\section{Acetylation regulation in ETI}

Acetylation of proteins are involved in plant defense mainly in two ways, the modification of histone to regulate gene expression, and the acetylation of non-histone proteins by pathogen type III effectors that function as acetyltransferase to alter plant immunity [SONG \& WALLEY, 2016]. Several pathogen effector proteins encode acetyltransferase enzymes that directly acetylate host proteins (e.g. RRS1, RPM1, WRKY and cell skeleton proteins) and alter plant immunity [SONG \& WALLEY, 2016]. Nucleotide binding leucine-rich repeat (NB-LRR) receptor protein was shown to interact with pathogen effector and the downstream immune response was down-regulated [LEE \& al. 2015]. Bacterial effector PopP2 acetylated the Cterminal WRKY transcription factor domain of RRS1 as well as WRKY transcription factors and abolished DNA binding activity and suppressed immunity [TASSET \& al. 2010; LE ROUX $\&$ al. 2015; SARRIS \& al. 2015]. Another pathogen effector, HopZ3, was shown to inactivate RPM1 immune complex by acetylating its members including RIN4 and RIPK [LEE \& al. 2015]. It was also reported that the acetylation of non-histone protein of maize by a plantencoded histone deacetylase was involved in immune response [WALLEY \& al. 2018].

\section{Other PTMs in ETI}

PTMs modulates the recognition of pathogen effectors at host-pathogen interface. Ubiquitination has been reported to up-regulate a virus induced ETI by targeting a protease and hence stabilize an R protein [LIM \& al. 2018]. Virus can express suppressors that inhibit host RNA silencing to facilitate infection and these suppressors can be recognized as effectors by plant R proteins and trigger ETI [CHOI \& al. 2004]. HRT, an R protein in Arabidopsis, can be activated by turnip crinkle virus (TCV) coat protein to trigger HR and resistance [LIM \& al. 2018]. Double stranded RNA binding protein (DRB) 1 and 4 play a role in stabilizing HRT and are required for resistance to TCV [LIM \& al. 2018]. TOP1, an E3 ligase, positively regulates TCV-induced ETI by negatively regulating proteases that target the degradation of DRB1 and DRB4 [LIM \& al. 2018]. $S$-acylation also plays a role in ETI. RPS5 is responsible for immune response during Pseudomonas syringae infection [QI \& al. 2012]. The activation of RPS5 was shown to require the cleavage of PBS1 protein kinase by AvrPphB, the effector of Pseudomonas syringae [QI \& al. 2014]. The localization of PBS1 to PM and its cleavage both required Nterminal $S$-acylation on its Cys residues [QI \& al. 2014].

SUMOylation modulates SA-dependent immune response and suppresses autoimmunity. SIZ1, a SUMO E3 ligase, regulates SA-dependent immune response by mediating SNC1 activity [GUO \& al. 2017]. Overexpression of TOPLESS-RELATED 1 (TPR1), a SUPPRESSOR OF npr1-1, CONSTITUTIVE 1 (SNC1)-interacting protein, resulted in autoimmunity that reduced plant growth and development [NIU \& al. 2019]. Loss of function of SIZ1, a SUMO E3 ligase, was shown to induce an autoimmune response, partially due to the elevated SNC1 levels [NIU \& al. 2019]. SIZ1 physically interacted with TPR1 and facilitated its SUMO modification, with K282 and K721 residues in TPR1 as critical sites for SUMO attachment [NIU \& al. 2019]. 


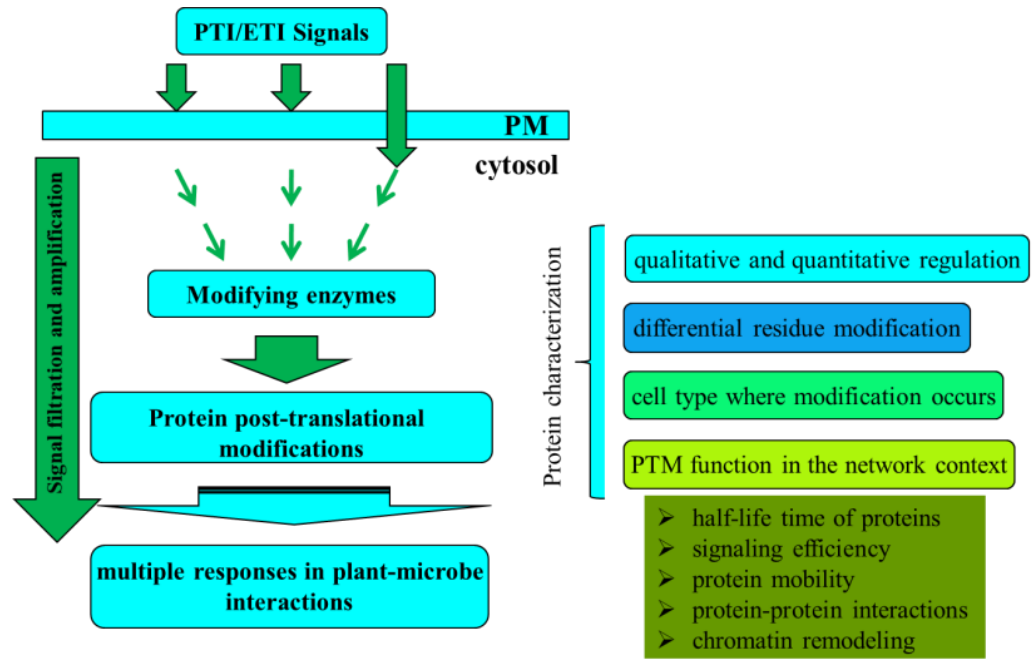

Figure 1. Post-translational modifications in plant defense mechanisms and challenges to research approaches

\section{Conclusions}

PTMs are used by plants to regulate immune response. Phosphorylation plays a critical role in defense signaling while other types of PTMs are increasingly shown to contribute to the regulation of plant-microbe interactions in various ways (Figure 1). Glycosylation works mainly in the preparation of the system by ensuring the production and translocation of the receptor. However, it is less involved during the modulation of signal transduction. This is probably because glycosylation is required for the maturing of protein and the process have to be done within ER and Golgi. The transportation of cytosolic signaling components into endomembrane system can be costly. On the other hand, ubiquitination is more dynamic and plays roles mainly in stabilizing the system rather than participating in signal transduction directly. The beauty of ubiquitination is that $\mathrm{Ub}$ can be attached to an individual protein precisely without affecting proteins in a complex. Taking this advantage, plant can finetune defense response accurately. For most of the time, a single immune signaling component is regulated by multiple other components and PTMs. This ensures the plant defense system in a resting state without pathogen and is turned on rapidly when a pathogen attacks. The components (e.g. BIK1) crosslink multiple pathways and are highly regulated. The advantage of PTM is that it does not involve transcription and many of them are reversible. This allows fast and accurate switch of physiology upon interaction with pathogen.

PTM study is much more challenging in the study of plant defense mechanisms as there is an additional interaction, i.e. the host plant and the microbe. A comprehensive understanding at PTM level with various forms of modifications is essential to uncover the mechanisms that govern this interaction and particularly the response by host plants. It is highly likely that detailed mechanisms of all types of PTMs remain to be elucidated. It is worth mentioning that some topics are covered by other recent reviews [WITHERS \& DONG, 2017; DE VEGA \& al. 2018; ZHANG \& ZENG, 2020]. 


\section{Notes on contributors}

Tim XING is an associate professor and a plant molecular biologist with a special interest in cell signaling and plant-microbe interactions. He teaches plant physiology, molecular plant development, and cell signaling. Ziwei GUO is a graduate student.

\section{Acknowledgements}

This work was supported by research grants to Tim XING from Natural Sciences and Engineering Research Council of Canada and Bayer Crop Science Inc. Canada.

\section{References}

AEBI M. 2013. $N$-linked protein glycosylation in the ER. Biochimica et Biophysica Acta. 1833(11): $2430-2437$. https://doi.org/10.1016/j.bbamcr.2013.04.001

BIGEARD J., COLCOMBET J. \& HIRT H. 2015. Signaling mechanisms in pattern-triggered immunity (PTI). Molecular Plant. 8: 521-539. https://doi.org/10.1016/j.molp.2014.12.022

CHAKRABORTY R., MACOY D. M., LEE S. Y., KIM W. \& KIM M. G. 2017. Tunicamycin-induced endoplasmic reticulum stress suppresses plant immunity. Applied Biological Chemistry. 60: 623-630. https://doi.org/10.1007/s13765-017-0319-3

CHEN X., SHANG J., CHEN D., LEI C., ZOU Y., ZHAI W., LIU G., XU J., LING Z., CAO G., MA B., WANG Y., ZHAO X., LI S. \& ZHU L. 2006. A B-lectin receptor kinase gene conferring rice blast resistance. Plant Journal. 46: 794-804. https://doi.org/10.1111/j.1365-313X.2006.02739.X

CHOI C. W., QU F., REN T., YE X. \& MORRIS T. J. 2004. RNA silencing-suppressor function of Turnip crinkle virus coat protein cannot be attributed to its interaction with the Arabidopsis protein TIP. Journal of General Virology. 85: 3415-3420. https://doi.org/10.1099/vir.0.80326-0

CUI H., TSUDA K. \& PARKER J. E. 2015. Effector-triggered immunity: from pathogen perception to robust defense. Annual Review of Plant Biology. 66: 487-511. https://doi.org/10.1146/annurev-arplant-050213-040012

DE VEGA D., NEWTON A. C. \& SADANANDOM A. 2018. Post-translational modifications in priming the plant immune system: ripe for exploitation? FEBS Letters. 592: 1929-1936. https://doi.org/10.1002/18733468.13076

DERKACHEVA M., YU G., RUFIAN J. S., JIANG S., DERBYSHIRE P., MORCILLO R. J., STRANSFELD L., WEI Y. L., MENKE F. L.H., ZIPFEL C. \& MACHO A. P. 2020. The Arabidopsis E3 ubiquitin ligase PUB4 regulates BIK1 homeostasis and is targeted by a bacterial type-III effector. bioRxiv. https://doi.org/10.1101/2020.10.25.354514

DODDS P. N. \& RATHJEN J. P. 2010. Plant immunity: towards an integrated view of plant-pathogen interactions. Nature Reviews Genetics. 11: 539-548. https://doi.10.1038/nrg2812

FARID A., MALINOVSKY F. G., VEIT C., SCHOBERER J., ZIPFEL C. \& STRASSER R. 2013. Specialized roles of the conserved subunit OST3/6 of the oligosaccharyl transferase complex in innate immunity and tolerance to abiotic stresses. Plant Physiology. 162: 24-38. https://doi.org/10.1104/pp.113.215509

FU Z. Q. \& DONG X. 2013. Systemic acquired resistance: turning local infection into global defense. Annual Review of Plant Biology. 64: 839-863. https://doi.org/10.1146/annurev-arplant-042811-105606

GUO M., HUANG Q., QIAN W., ZHANG Z., JIA Z. \& HUA J. 2017. SUMOylation E3 ligase SIZ1 modulates plant immunity partly through the immune receptor gene SNC1 in Arabidopsis. Molecular Plant-Microbe Interactions. 30: 334-342. https://doi.org/10.1094/MPMI-02-17-0041-R

HÄWEKER H., RIPS S., KOIWA H., SALOMON S., SAIJO Y., CHINCHILLA D., ROBATZEK S. \& VON SCHAEWEN A. 2010. Pattern recognition receptors require $N$-glycosylation to mediate plant immunity. Journal of Biological Chemistry. 285: 4629-4636. https://doi.org/10.1074/jbc.M109.063073

JIA X., ZENG H., WANG W., ZHANG F. \& YIN H. 2018. Chitosan oligosaccharide induces resistance to Pseudomonas syringae pv. tomato DC3000 in Arabidopsis thaliana by activating both salicylic acid- and jasmonic acidmediated pathways. Molecular Plant-Microbe Interactions. 31: 1271-1279. https://doi.org/10.1094/MPMI03-18-0071-R

JIA X., ZENG H., BOSE S. K., WANG W. \& YIN H. 2020. Chitosan oligosaccharide induces resistance to Pst DC3000 in Arabidopsis via a non-canonical $N$-glycosylation regulation pattern. Carbohydrate Polymers. 250: 116939. https://doi.org/10.1016/j.carbpol.2020.116939

KANG B. S., BAEK J. H., MACOY D. M., CHAKRABORTY R., CHA J., HWANG D., LEE Y. H., LEE S. Y. \& KIM M. G. 2015. N-glycosylation process in both ER and Golgi plays pivotal role in plant immunity. Journal of Plant Biology. 58: 374-382. https://doi.org/10.1007/s12374-015-0197-3 
LE ROUX C., HUET G., JAUNEAU A., CAMBORDE L., TREMOUSAYGUE D., KRAUT, A., ZHOU B. B., LEVAILLANT M., ADACHI H., YOSHIOKA H., RAFFAELE S., BERTHOMÉ R., COUTÉ Y., PARKER J. E. \& DESLANDES L. 2015. A receptor pair with an integrated decoy converts pathogen disabling of transcription factors to immunity. Cell. 161: 1074-1088. https://doi.org/10.1016/j.cell. 2015.04.025

LEE J., MANNING A. J., WOLFGEHER D., JELENSKA J., CAVANAUGH K. A., XU H., FERNANDEZ S. M., MICHELMORE R. W., KRON S. J. \& GREENBERG J. T. 2015. Acetylation of an NB-LRR plant immuneeffector complex suppresses immunity. Cell Reports. 13: 1670-1682.

https://doi.org/10.1016/j.celrep.2015.10.029

LIANG X., DING P., LIAN K., WANG J., MA M., LI L., LI L., LI M., ZHANG X., CHEN S., ZHANG Y. \& ZHOU J. M. 2016. Arabidopsis heterotrimeric G proteins regulate immunity by directly coupling to the FLS2 receptor. eLife. 5: e13568. https://doi.org/10.7554/eLife.13568

LIM G., HOEY T., ZHU S., CLAVEL M., YU K., NAVARRE D., KACHROO A, DERAGON J. M. \& KACHROO P. 2018. COP1, a negative regulator of photomorphogenesis, positively regulates plant disease resistance via double-stranded RNA binding proteins. PLoS Pathogens. 14(3): e1006894. https://doi.org/10.1371/journal.ppat.1006894

LU D., LIN W., GAO X., WU S., CHENG C., AVILA J., HEESE A., DEVARENNE T. P., HE P. \& SHAN L. 2011. Direct ubiquitination of pattern recognition receptor FLS2 attenuates plant innate immunity. Science. 332: 1439-1442. https://doi.org/10.1126/science.1204903

NEWMAN M. A., SUNDELIN T., NIELSEN J. T. \& ERBS G. 2013. MAMP (microbe-associated molecular pattern) triggered immunity in plants. Frontiers in Plant Science. 16: 139. https://doi.org/10.3389/fpls.2013.00139

NIU D., LIN X. L., KONG X., QU G. P., CAI B., LEE J. \& JIN J. B. 2019. SIZ1-mediated SUMOylation of TPR1 suppresses plant immunity in Arabidopsis. Molecular Plant. 12: 215-228. https://doi.org/10.1016/j.molp.2018.12.002

OROSA B., YATES G., VERMA V., SRIVASTAVA A. K., SRIVASTAVA M., CAMPANARO A., DE VEGA D., FERNANDES A., ZHANG C., LEE J., BENNETT M. J. \& SADANANDOM A. 2018. SUMO conjugation to the pattern recognition receptor FLS2 triggers intracellular signalling in plant innate immunity. Nature Communications. 9: 5185. https://doi.org/10.1038/s41467-018-07696-8

QI D., DEYOUNG B. J. \& INNES R. W. 2012. Structure-function analysis of the coiled-coil and leucine-rich repeat domains of the RPS5 disease resistance protein. Plant Physiology. 158: 1819-1832. https://doi.org/10.1104/pp.112.194035

QI D., DUBIELLA U., KIM S. H., SLOSS D. I., DOWEN R. H., DIXON J. E. \& INNES R. W. 2014. Recognition of the protein kinase AVRPPHB SUSCEPTIBLE1 by the disease resistance protein RESISTANCE TO PSEUDOMONAS SYRINGAE5 is dependent on s-acylation and an exposed loop in AVRPPHB SUSCEPTIBLE1. Plant Physiology. 164: 340-351. https://doi.org/10.1104/pp.113.227686

SALEH A., WITHERS J., MOHAN R., MARQUES J., GU Y., YAN S., ZAVALIEV R., NOMOTO M., TADA Y. \& DONG X. 2015. Posttranslational modifications of the master transcriptional regulator NPR1 enable dynamic but tight control of plant immune responses. Cell Host Microbe. 2: 169-182. https://doi.org/10.1016/j.chom.2015.07.005

SARRIS P. F., DUXBURY Z., HUH S. U., MA Y., SEGONZAC C., SKLENAR J., DERBYSHIRE P., CEVIK V., RALLAPALLI G., SAUCET S. B., WIRTHMUELLER L., MENKE F., SOHN K. H. \& JONES J. 2015. A plant immune receptor detects pathogen effectors that target WRKY transcription factors. Cell. 161: 10891100. https://doi.org/10.1016/j.cell.2015.04.024

SKELLY M. J., MALIK S. I., BIHAN T. L., BO Y., JIANG J., SPOEL S. H. \& LOAKE G. J. 2019. A role for $S$ nitrosylation of the SUMO-conjugating enzyme SCE1 in plant immunity. Proceedings of the National Academy of Sciences USA. 116: 17090-17095. https://doi.org/10.1073/pnas.1900052116

SONG G. \& WALLEY J. W. 2016. Dynamic protein acetylation in plant-pathogen interactions. Frontiers in plant science. 7: 421. https://doi.org/10.3389/fpls.2016.00421

SUN W. X., CAO Y. R., LABBY K. J., BITTEL P., BOLLER T. \& BENT A. F. 2012. Probing the Arabidopsis flagellin receptor: FLS2-FLS2 association and the contributions of specific domains to signaling function. Plant Cell. 24: 1096-1113. https://doi.org/10.1105/tpc.112.095919

TANG D., WANG G. \& ZHOU J. M. 2017. Receptor kinases in plant-pathogen interactions: more than pattern recognition. Plant Cell. 29: 618-637. https://doi.org/10.1105/tpc.16.00891

TASSET C., BERNOUX M., JAUNEAU A., POUZET C., BRIERE C., KIEFFER-JACQUINOD, S., RIVAS S., MARCO Y. \& DESLANDES L. 2010. Autoacetylation of the Ralstonia solanacearum effector PopP2 targets a lysine residue essential for RRS1-R-mediated immunity in Arabidopsis. PLoS Pathogens. 6: e1001202. https://doi.org/10.1371/journal.ppat.1001202

TREMPEL F., KAJIURA H., RANF S., GRIMMER J., WESTPHAL L., ZIPFEL C., SCHEEL D., FUJIYAMA K. \& LEE J. 2016. Altered glycosylation of exported proteins, including surface immune receptors, compromises 
calcium and downstream signaling responses to microbe-associated molecular patterns in Arabidopsis thaliana. BMC Plant Biology. 16: 31. https://doi.org/10.1186/s12870-016-0718-3

TREMPEL F., ESCHEN-LIPPOLD L., BAUER N., RANF S., WESTPHAL L., SCHEEL D. \& LEE J. 2020. A mutation in asparagine-linked glycosylation 12 ( ALG12) leads to receptor misglycosylation and attenuated responses to multiple microbial elicitors. FEBS Letters. 594: 2440-2451. https://doi.org/10.1002/1873-3468.13850

VAN DER HOORN R. A., WULFF B. B., RIVAS S., DURRANT M. C., VAN DER PLOEG A., DE WIT, P. J. \& JONES J. D. G. 2005. Structure-function analysis of $\mathrm{cf}-9$, a receptor-like protein with extracytoplasmic leucine-rich repeats. Plant Cell. 17: 1000-1015. https://doi.org/10.1105/tpc.104.028118

WALLEY W. J., SHEN Z., MCREYNOLDS R. M., SCHMELZ A. E. \& BRIGGS P. S. 2018. Fungal-induced protein hyperacetylation in maize identified by acetylome profiling. Proceedings of the National Academy of Sciences USA. 115: 210-215. https://doi.org/10.1073/pnas.1717519115

WANG J., QU B., DOU S., LI L., YIN D., PANG Z., ZHOU Z., TIAN M., LIU G., XIE Q., TANG D., CHEN X. \& ZHU L. 2015. The E3 ligase OsPUB15 interacts with the receptor-like kinase PID2 and regulates plant cell death and innate immunity. BMC Plant Biology. 15: 49.

https://doi.org.proxy.library.carleton.ca/10.1186/015-0442-4

WANG J., GRUBB L. E., WANG J., LIANG X., LI L., GAO C., MA M., FENG F., LI M., LI L., ZHANG X., YU F., XIE Q., CHEN S., ZIPFEL C., MONAGHAN J. \& ZHOU J. M. 2018. A regulatory module controlling homeostasis of a plant immune kinase. Molecular Cell. 69: 493-504.e6. https://doi.org/10.1016/j.molcel.2017.12.026

WITHERS J. \& DONG X. 2017. Post-translational regulation of plant immunity. Current Opinion in Plant Biology. 38: 124-132. https://doi.org/10.1016/j.pbi.2017.05.004

XING T. \& LAROCHE A. 2011. Revealing plant defense signaling: getting more sophisticated with phosphoproteomics. Plant Signaling \& Behavior. 6: 1469-1474. https://doi.org/10.4161/psb.6.10.17345

XING T., LI X. Q., LAROCHE A., TIAN L., TUBEI K. \& WANG X. J. 2017. Protoplasts in the analysis of early plantpathogen interactions: current applications and perspectives. European Journal of Plant Pathology. 149: 1001-1010. https://doi.org/10.1007/s10658-017-1230-9

YAMAGUCHI K., MEZAKI H., FUJIWARA M., HARA Y. \& KAWASAKI T. 2017. Arabidopsis ubiquitin ligase PUB12 interacts with and negatively regulates chitin elicitor receptor kinase 1 (CERK1). PLoS One. 12(11): e018886. https://doi.org/10.1371/journal.pone.0188886

ZHANG Y. \& ZENG L. 2020. Crosstalk between ubiquitination and other post-translational protein modifications in plant immunity. Plant Communications. 1: 100041. https://doi.org/10.1016/j.xplc.2020.100041

How to cite this article:

XING T. \& GUO Z. 2021. Recent advances in post-translational regulation of plant defense responses beyond phosphorylation. J. Plant Develop. 28: 151-159. https://doi.org/10.47743/jpd.2021.28.1.884 